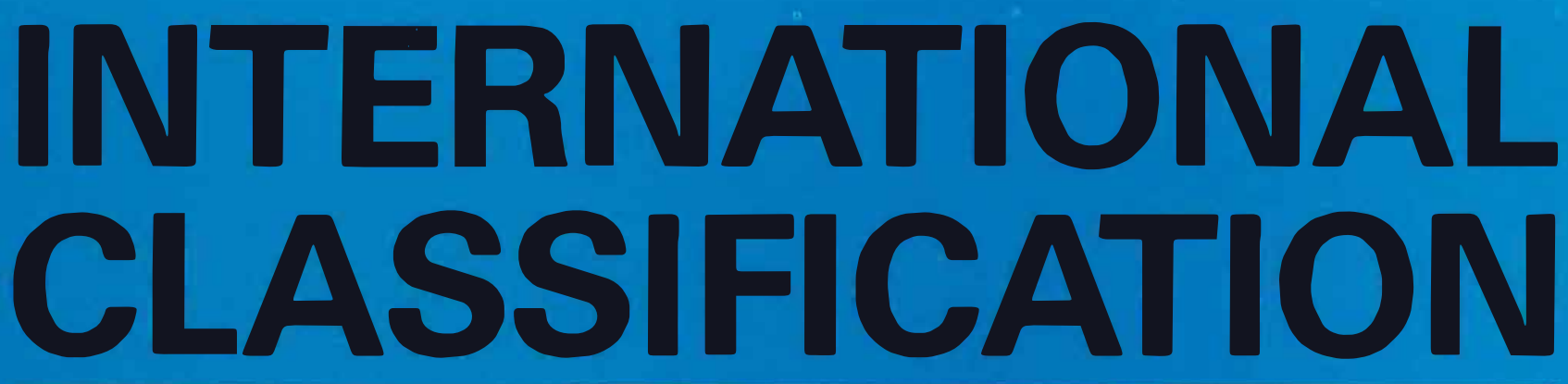

Journal on Theory and Practice of Universal and Special Classification Systems and Thesauri Zeitschrift zur Theorie und Praxis universaler und spezieller Klassifikationssysteme und Thesauri

\title{
Editors/Herausgeber
}

Dr. I. Dahlberg, Frankfurt, BRD (Editor-in-Chief)

Prof. Dr. Dr. A. Diemer, Düsseldorf, BRD

Prof. A. Neelameghan, Bangalore, India

Prof. J. M. Perreault, Huntsville, Ala., USA

co-sponsored by FID/CR

and by the IFLA International Office for UBC

in collaboration with/in Zusammenarbeit mit

Prof. P. Atherton, Syracuse, N.V., USA

Dipl. Math. H. Fangmeyer, Ispra, Italy

Dipl.-Volksw. O. Gekeler, UIm, BRD

Prof. E. de Grolier, Paris, France

Dr. F. Lang, Vienna, Austria

Cons. Eng. V. Nakamura, Tokyo, Japan

Dr. E. Scibor, Warsaw, Poland

Prof. Dr. D. Soergel, College Park, Md., USA

Prof. Dr. R. Sokal, Stony Brook, N.V., USA

Prof. A. L. C. Vicentini, Brasilia, Brasil

Prof. B. C. Vickery, London, England

Prof. Dr. E. Wüster, Wieselburg, Austria

and the Forschungsabt. Information und Dokumentation

des Philosophischen Instituts, Universität Düsseldorf

(Direktor: Prof. Dr. N. Henrichs)

Verlag Dokumentation, Publishers, München 


\section{Contents / Inhalt}

Editorial

Letters to the Editor

Articles - Aufsätze

G. Gehring: Das Stich- und Schlagwörterverzeichnis zur deutschen Ausgabe der Internationalen Patentklassifikation (The subject index to the German Edition of the Intern. Patent Class.)

Y. Nakamura: Automatic production of indexes from schedules

E. de Andrade Oliveira: An automatic index in natural language for UDC Editions

J. Hölzl: Probleme der Warenbeschreibung und Klassifikation (Problems of commodity description and classification)

\section{Reports and Communications}

H. Leclercq: Collaboration internationale dans Ie domaine de la Terminologie scientifique et technique - Le Symposium d'Infoterm. Vienne, 9-11 avril 75 The 1975 Classification Society Meeting, North Amer. Branch

Meetings of The Classification Society, European Branch

H. Schürkens: Material data management today and tomorrow - A NATO

Symposium at Copenhagen

H. Borko: Printed Subject Indexes - The Aberystwyth Institute 1975

A. L. C. Vicentini: Classification at the 8 th IBBD Congress, Brasilia

I. Dahlberg: Sth International Congress on Logic, Methodology and Philosophy of Science, Canada

Seminario di Studi sulla C. D. U.; ISO/TC 37/WG 4 Constituting Meeting;

Conference celebrating the Dewey Centenary; Proposals for standardization of classification terms; Klassifikation und Beschreibung von Forschungsobj. Curriculum in Classification BSO under Preparation for Field Testing - Revised Subject-Fields Scheme for German Universities - Classification of Current Research Projects

Terminology Corner: Concerning thesaurus terminology

Book Reviews - Buchbesprechungen

Ökonomische Semiotik

Gekeler/Herdt/Oberender: Warenkatalogisierung und Kommunikation fiber die Ware.

(H. Körner)

Austin, D.: PRECIS: a manual of concept analysis and subject indexing. (Ph. Richmond)

Hicks, S. C.: Classification research (Australia). (T, Morgan)

Rigby, M.: Computers and the UDC. (K.-H. Koch)

Grundke, G.: Grundriß der allgemeinen Warenkunde (O. Gekeler)

Stammerjohann/Janssen: Handbuch der Linguistik. (R. Kuhlen)
Vogel, F.: Probleme und Verfahren der numerischen Klassifikation. (Fangmeyer)

Daniel/Mills: A classification of library and information science. (H. Körner)

Classification Literature 2 (1975) No. 2, Nos. 1127-1495

\section{INTERNATIONAL \\ CLASSIFICATION}

Journal on Theory and Practice of Universal and Special Classification Systems and Thesauri

Zeitschrift zur Theorie und Praxis universaler und spezieller Klassifikationssysteme und Thesauri

\section{Editorial Office/Redaktion:}

c/o Dr. I. Dahlberg, D-6 Frankfurt 50 Woogstr. 36a, Tel.: (0611) 523690

Issue frequency/Erscheinungsweise: 2 x/ann.

\section{Publisher/Verlag:}

Verlag Dokumentation Saur KG, P.O.B. 711009 , Pössenbacher Str. 2, D-8000 München 71, Bundesrepublik Deutschland, Tel.: (089) 798901,

Telex: 5212067 saur $d$

Annual Subscription Rates/Abonnement: DM 36,-. For members of national or international classification societies or groups DM 27,-/Für Mitglieder nationaler oder internationaler Klassifikationsgesellschaften oder -gremien DM 27,-Single issue/Einzelheft: DM 20,-

Advertising prices/Anzeigenpreisliste $1 / 74$

\section{Bankverbindungen:}

Postscheckkonto München 2061 41-804; Bayer. Hypotheken- und Wechselbank, München, Kto. Nr. 3388662

\section{Printed by/Druck:}

Anton Hain KG, D.6554 Meisenheim/Glan

All rights reserved/Alle Rechte vorbehalten. Printed in West Germany 1975

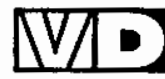

\section{Verlag Dokumentation. Publishers}

Editors/Herausgeber:

Dr. phis Ingetraut Dahlberg. D-6 Frankfurt 50 Woogstr. 36a, BRD

Prof. Dr. med. Dr. phil Alwin Diemer, Philosophisches Institut der Universität Düsseldorf, D-4 Düsse dorf 1, Universitätsstr. 1, BRD Prof. Jean M. Perreault, Director of the University
Library, University of Alabama. P.D.B. 1247 Hunts ville, Alabama 35807 , USA

Prof. Arashanipalai Neelameghan, Documentation Research and Training Centre (DRTC), 112 Cros co-sponsored by FID/CR (Fédération Internationale de Documentation. Committee on Classification Research), address see Prof. A. Neelameghan and by the International Federation of Library Associations (IFLA) international Office for UBC, Director: Mrs. D. Anderson, c/o The British Library. Ref. Div., London WC1B 3DG, England

Consulting Editors/Redaktionsbeirat: Prof, Pauline Atherton, School of Library Science Syracuse University, Syracuse, N. Y., 13210 USA Dipl. Math. Hermann Fangmeyer, Euratom CCR C. E. T. I. S. (European Scientific Information Processing Centre), 1-21020 ispra (Varese) Italy Dipl. Volksw. Dtto Gekeler, ARG-Telefunken (N1) 79 Ulin, Postfach 830, BRD

Prof. Eric de Grolier, Conseil International des Sciences, 1, rue Miollis, F-75 Paris 15e, France
Dr. Friedrich Lang, 18M, A-1040 Wien, Margarethenstr. 3/4, Austria

Yukio Nakamura, Authorized Consulting Engineer 14-8 Nisikata-1 Bunkyo-Ku. Tokyo 113. Japan Dr. Eugen Scibor, Institut Informacji Naukowej. Technicznej i Ekonomicznei (IINTEI, Al. Niepodleglości 188. Warszawa, Poland

Prof. Dr. Dagobert Soergel, School of Library and Information Services, University of Maryland. College Park, Md., 20742 USA

Prof. Dr. Robert R. Sokal, State University of New York, Stony Brook, New York 11 794, USA Prof. Abner L.C. Vicentini. Ministerio das Minas e Energia, Esplanada dos Ministerios, Bloco $J-9$. Prof. Bryan C. Vickery, School of Library, Archive Prof. Bryan C. Vickery, School of Library, Archive
and Information Studies, University College, Gower and Information Studies, Universi

Prof. Dr. Eugen Wüster, A 3250 Wieselburg, Austria in collaboration with/in Zusammenarbelt mit: Forschungsabteilung information und Dokumentation des Philosophischen instiluts der Universität Düsseldorf, O-4 Dusseldorf, Unive

Authors of this issue/Autorerl dieses Heftes: Dr. Gerhard Gehring, Ltd. Reg. Dir., Deutsches Pa. tentamt, 8 M/jinchen 2, Zweibrückerstr. 12 Cons. Eng. Y. Nakamura, see above
Mrs. E. de Andrade Oliveira, Instituto Brasileiro de Bibliografia e Documentacấ, Av. General Justo, 171 Rio de Janeiro, Brasil

Prof. Dr. J. Höizl, Institut für Technologie und Werenwirtschaftslehre der Hochschule für Welthandel, A 1190 Wien, Franz Klein-Gasse

Dr. H. Leclerca, Lentelaan 1, 8-3040 Korbeek-Lo Mr. H. Schürkens, Head, Codification Offico, NATO, B-1100 Brussels

Prof. Dr. Harold Borko, Graduate School of Library Science, University of California, Los Angeles, Calif. 90024, USA

Prof, A. L. C. Vicentini, see above

I. Dahlberg. see above

O. Gekelor, see above

H. Körner, M. S. Beratung für computerisierte Infor mations- und Dokumentationssysteme, 8 München 40 Zittelstr. 5

Prof. Dr. Phyllis Richmond, School of Library Science. Case Western Reserve University, Cleveland, Ohiø. 44106, USA

Prof. T. S. Morgan, Polytechnic of North London, School of Librarianship. Essex Road 207-225, London N1 3PN, England

Mr. K. Koch.Zentralstelle für Maschinelle Dokumen. tation, D-6 Frankfurt 71, Herriotstr. 5 Doz. R. Kuhlen, Lehrinstitut für Dokumentation, DGD, D-6 Frankfurt 1, Westendstr. 19 Dipt. Math. H. Fangmeyer, see above Prof. Dr. F. Vogel, Institut für Statistik und Okono metrie der Chr.-Albrechts-Universität Kiel D-23 Kiel,
Olshausenstr.40-60 
UDC $025.4(05)$

INTERNATIONAL CLASSIFICATION

Vol. 2 (1975) No. 2, p. 71-144, Nov. 1975

Journal on Theory and Practice of Universal and Special Classification Systems and Thesauri

Zeitschrift zur Theorie und Praxis ınirersaler und spezieller Klassifikationssysteme und Thesauri

Publisher:

Verlag Dokumentation Saur KG, P.O.Box, Pössenbacher Str. 2, D-8000 München 71, BRD

Tel.: (089) 798901, Telex 5212067 saur d

Editorial offices:

Issue frequency/

Erscheinungswe/se: 2/ann.; Subscription/Preis: DM 36,-/ann.

\section{Contents page / Inhaltsfahne}

This contents page may be reproduced without charge - Diese lnhaltsfahne darf gebührenfrei vervielfältigt werden (DIN 1428)

Gehring, G.: Das Stich- und Schlagwörterverzeichnis zur deutschen Ausgabe der Internationalen Patentklassifikation. (The subject index to the German edition of the International Patent Classification) (In German)

In: Intern. Classificat. 2 (1975) No. 2, p. 73-80

Description of the methods and the programming system used for the establishment of a comprehensive subject index to the German version of the International Patent Classification (Int. Cl.). The familiar KWIC or KWOC method could not be applied here since the terms in the text of the class descriptions are of such a general type that they would have referred to fifty and more different units of the Int. $\mathrm{Cl}$. Instead, the index was created by using in addition to a keyword extracting method (Stichwortmethode) the descriptor assignment method (Schlagwortmethode). The assignment was accomplished through the cooperation of the German, Austrian and Swiss Patent Offices with altogether about 800 examiners involved in the work. Approx. 50000 keywords and additional descriptors were combined and permuted via a programming system resulting in over 113000 alphabetically sorted entries of two keywords or descriptors each and referring to the notations of the Inc. $\mathrm{Cl}$. class descriptions.

(Author)

Nakamura, Y.: Automatic production of indexes from schedules. The case of Universal Decimal Classification.

In: Intern. Classificat. 2 (1975) No. 2, p. $81-88$

The automatic preparation of indexes from schedules causes a reduction in the total cost of a UDC edition by minimizing the keyboard operation, provided that the printing is made through computer input. The author discusses how the schedule text should be subjected to certain modifications (conforming to the TOCS principle) to facilitate the transformation of schedule into an index entry. In Part $A$ the shortcomings of existing text with a view to computer processing is discussed and measures are proposed. In Part B, taking into consideration such measures, a system of processing is proposed to implement the schedule-index inversion. The Appendix gives a brief description of the concept of TOCS (term-oriented classification system) and of a few cases where it has been implemented.
Oliveira, E. de Andrade: An automatic index in natural language for UDC editions.

In: Intern. Classificat. 2 (1975) No. 2, p. 89-93

Description of the procedures for and the advantages of the automatic creation of index entries from the class descriptions in the schedules of the UDC. Examples show the addings to or alterations of the class descriptions in order that the index entries may be truly informative about the concept contained in a "classification number" (UDC-notation). In the annex sample pages are given of the computer printouts, listing the cards, the entries in the schedule and the entries in the index, all relating to one sample page of UDC 53, Physics (532.614-533.42). (I.C.)

Hölzl, J.: Probleme der Warenbeschreibung und Klassifikation. (Problems of commodity description and classification.) In: Intern. Classificat. 2 (1975) No. 2, p. 94-102

The structural principles necessary for a complete description of commodities serving all kinds of purposes have been developed tentatively. Characteristics of commodities may be taken from a system of three main levels of chararcteristics: a formal-logical level, a scientific technical one and an economic-legal one. A fourth kind of level will have to be reserved for some special and additional kinds of characteristics. A computerized commodity description may be built up by teams of specialists formulating and presenting commodity characteristics and their kinds in a serial question-answer form. Names and/or designations of commodities (products, articles, groups of classes of products) should be collected in thesauri of commodity-terms with the necessary relationships indicated in order to ensure a controlled use of these names/terms in commodity description. (Author) 


\section{Special Prepublicution Offer! Europa-Administration}

Handbuch der Verwaltung und Justiz fïr die Europäische Gemeinschaft Répertoire de l'Administration et de la Justice pour la Communauté Européenne Administratief en Gerechtelijk Handboek voor de Europese Gemeenschap Directory of Administration and Justice for the European Community Manuale dell'Amministrazione e della Giustizia per la Comunita Europee Prirucnnik Sudskih i Administrativnih Ustanova Zemalja Evropske Zajednice Editor: Walter Z. Duic

1976. approx. 1200 pages. 9 maps. Linson approx. DM 180.00. ISBN 3-7940-3017-6 PREPUBLICATION PRICE UNTIL JANUARY 31, 1976: DM 148.00

This handbook provides detailed coverage of the states of the European Community in more than 16,000 entries, thus giving evidence of current developments and expanding relations between these states in the fields of public administration, trade and industry, labor administration and social service, administration of justice and tourism.

Each entry comprises: Abbreviation and acronym of the superordinate and of the subordinate administrative bodies, name and designation of authority or institution; complete address including zip code, telephone number with area code, TX number; name of chief government or institutional official (when available). Listings are based on the most recent information available; names of chief officials of authorities and institutions are as of January 1975.

Listings are in six languages: German - French - Dutch - English - Italian - Serbo-Croatian. Geographical place names are given in the common form of the respective country.

The handbook covers the following countries: Federal Republic of Germany - France - Italy - The Netherlands Belgium - Great Britain - Northern Ireland - Denmark - Eire - Luxembourg.

\section{Who's Who in Eastern Europe}

Biographic data on important personalities from politics, economics and culture in nine Eastern European countries with an appendix for the People's Republic of China, Mongolie, (North) Vietnam, North Korea and Cuba. Editors: Boris Lewytzkyj and Juliusz Stroynowski

1976. approx. 1000 pages. Linson, approx. DM 198.00. ISBN 2-7940-3193-8 In English language

PREPUBLICATION PRICE UNTIL JUNE 30, 1976: DM 148.00

Some 12,000 biographies of Eastern European politicians, economic leaders, artists, writers and scientists provide a remarkable insight view into the world of Eastern countries.

No information given in an entry is older than 2 years at the utmost. The personal lives of political, economic and cultural leaders from the following countries are given account of: German Democratic Republic, Poland, Czechoslovakia, Hungaria, Rumania, Bulgaria, Albania, Yugoslavia, USSR, Mongolia, People's Republic of China, North Vietnam, Cuba. North Korea. The USSR is represented with biographic details of some $\mathbf{4 0 0 0}$ persons.

These biographic data include: name, date of birth, party affiliation, nationality, education, present and former positions, political activities, decorations, awards prizes.

This reference book will be published in English. Current usefulness and lasting reference value make it a unique contribution to biographic handbooks on East European countries and it will surely prove to be of more than just transitory interest.

\section{World Guide to Universities}

= Handbook of International Documentation and Information, Vol. 10 Vol. I: EUROPE, Index

1975. Second, enlarged edition. Volume $I$ in two parts. approx. 2000 pages. Linson, approx. DM 298.00. ISBN 3-7940-1130-9

PREPUBLICATION PRICE UNTIL JANUARY 31, 1976: DM 240.00

The second edition of the World Guide to Universities covers 638 universities and colleges that offer doctoral degree programs and postdoctoral studies leading to teaching qualification on university level (habilitation) in 30 European countries. Many newly established institutions and structural reorganization, as in the case of the Sorbonne, that led to a splitting up of old universities into several autonomous institutions, added to a total increase of entries by 225 compared with the first edition.

Entries include: Name of the university, the college or the academy - Address, telephone, telex - Y ear of foundation - Student enrolment - President, vice-president, chancellor and vice-chancellor - University library, address, name of the director - Faculties or departments and their affiliated schools and institutes - Academic staff members; within the listing of each faculty or department name of the person is followed by his or her special subject field.

\section{Verlag Dokumentation, Publishers \\ D-8000 München 71, Pössenbacherstr. 2, P.O.B. 7110 09, Federal Republic of Germany Phone (089) 7989 01, 798902,7989 03, Telex 5212067 saur d}

